\title{
Effect of Learning Media Based on Combination of Mind-Manager and Wonder Share Quiz Creator towards Students' Learning Outcomes and Creative Thinking Skills
}

\author{
Amiruddin Kasim \\ Tadulako University \\ Palu, Indonesia \\ kasimamir@yahoo.co.id
}

\author{
Sri Wahyuni \\ Tadulako University \\ Palu, Indonesia \\ sriwahyunibioeduunm@ymail.com
}

\begin{abstract}
This study used a quasi-experiment with pretest-posttest control group design. The study aimed to test an effect of learning media application based on mindmanager combined wonder-share quiz creator on learning outcomes and creative thinking skill of students. The population of the study was the whole of the class Grade XI Science, totaling 127 students for four classes. The samples consisted of students of grade XI Science-1 as an experimental class and grade XI Science-2 as the control class, and of each class numbered 31 students. The sampling technique used a random assignment. The data were analyzed by descriptive and inferential statistical analysis. The result of statistics descriptive analysis showed that the average value of students' achievement for the experimental group and the control group was different. The result of inferential statistics analysis rejected null hypothesis, implementing that learningmedia application based on mind-manager combined wonder-share quiz creator can affect on learning outcomes and creative thinking skill
\end{abstract}

Keywords-Learning Media Based Mind-Manager; Wonder-Share Quiz Creator; Achievement; Creative Thinking skills

\section{I.INTRODUCTION}

Efforts of the education quality in Indonesia are currently held using many programs such as the improvement of curriculum, teacher certification, and the development of learning sets with Technological Pedagogical Content Knowledge (TPACK) framework. Ironically, it was not able to deliver a significant impact in improving the quality of the education. One of the most important components in the curriculum is a learning process and the quality of teachers. The teachers' role is not only as a transformer but also required to have creativity and innovation in classroom management and development of learning sets, of that has integrated with TPACK's framework. To face many challenges in this modern era, teachers have to apply innovative, inspiring, fun, challenging and motivating learning method [1]. To reach that kind of requirements, teachers need any interesting learning media by using computerized digital media called ICT. The use of media is expected to regenerate the motivation, boost the creativity and improve the student's outcome because the media is one of communication devices that will be useful in conveying messages in the learning process.

Based on the results of preliminary observations held in SMAN 5 Palu to biology teachers obtained information that the learning activities in the schools tend to be passive, and the model used in the study are still monotone, used one learning model only.Efforts to increase and to develop the creativity of students in the school have not been fully implemented. In addition, the ability of students to think more creative is still less overlooked by the teachers. The students have not been trained in providing an alternative some problemsolving.Therefore, it is necessary to develop an attractive learning media. Medium based mind-manager is one of many learning media that is expected to affect students' ability to think creatively because the mind-manager contains concepts mapping program and it can be used as a lane for students to channel their thoughts and ideas in solving the problem. Concept mapping is expected to upgrade creative thinking abilities of students in studying, resulting in more meaningful of the biological lessons 1 [2].

Based on the problems mentioned above, it is necessary to a research about the application of learning media based mindmanager collaborated with the wonder-share quiz creator in learning biology SMAN 5 Palu. According to [3] that using the media in teaching and learning process bring out new interest, motivation, and stimulation in the learning activities. This mind-manager media with ICT can help students and teachers in the learning process by summarizing huge subject matters into a few pages only [4].

Mind-manager media is combined with the wonder-share quiz creator. This media becomes one interactive learning media [5]. Wonder-share quiz creator is an interactive learning media that contains many questions presented in quiz form by using interactive quiz -maker application. Even though the learning media is combined, but mind-manager 
media is the main learning media while wonder-share quiz creator is a model of the learning evaluation. The purpose of mind-manager based media combined with questions generator application, wonder-maker quiz creator is to ease the teacher in providing many questions to solve as exercises after learning process using concept maps.oughts, he questions generator application, the future is not only composing many questions but also it provides an interesting layout or display and also various form of questions, and hence learning and problem-solving process can be more interesting and fun. This media is expected to make students more motivated.

\section{II.METHOD}

This study used a quasi-experimental study (quasiexperiment), with a pretest-posttest control group design that consisted of two groups. The first group is treated with mindmanager-based learning combined with wonder-share quiz creator, and the second group did not use the media, as a control group. The study design model used is as shown in Table I.

TABLE I. StUdy DESIGN MODEL

\begin{tabular}{|c|c|c|c|}
\hline Group & Pretest & Treatment & Posttest \\
\hline $\mathrm{A}$ & $\mathrm{O}_{1.1}, \mathrm{O}_{1.2}$ & $\mathrm{X}_{1}$ & $\mathrm{O}_{2.1}, \mathrm{O}_{2.2}$ \\
\hline $\mathrm{B}$ & $\mathrm{O}_{3.1}, \mathrm{O}_{3.2}$ & $\mathrm{X}_{2}$ & $\mathrm{O}_{4.1}, \mathrm{O}_{4.2}$ \\
\hline
\end{tabular}

(Source: Sugiyono, 2011))* [6]

The population of the study was all of the 11th Grade Science students in SMAN 5 Palu in the academic year 2016, mounted totally 127 students, divided into 4 classes. The sample in this study was 62 for 11th Grade Science students in SMAN 5 Palu which is divided among 31 students as an experimental group and 31 students as the control group. Besides that, sampling method that will be used is assignment random to class method [7].

Data were collected through two stages, namely preparation and implementation stage. Instruments used in the study is latest numbered 25 questions.earning result of students was validated by an expert and observation sheet was adjusted by creative thinking indicators.

The data wsere analyzed by using descriptive and inferential statistics. Learning result or learning outcome was analyzed by descriptive statistics, while to test a hypothesis was analyzed by inferential statistics, known as the independent t-test. The testing criterion is $\mathrm{H}_{0}$ was accepted if a significant level was less than $5 \%($ sig. $<\alpha=0,05)$ that means there was a difference between the two means of experimental and the control group. On the other hand, $\mathrm{H}_{0}$ is rejected if significant level is more than $5 \%$ (sig. $>\alpha=0,05$ ) that means there were insignificant differences between experimental and control group or there is no effect on learning result and students' ability in thinking creative between the students treat by mind-manager based media learning combined with wonder-share quiz creator and the control group

\section{III.RESULT AND DISCUSSION}

\section{A. Descriptive Statistics Analysis}

Descriptive analysis statistics was obtained from the mean of students score after being given mind-manager-based media learning. The scores mean was 80.77 , while the scores mean of the control group was 75.48. As such, the study shows that there is a significant effect of the application of mindmanager-based learning media and wonder-share quiz creator.

Mean (average) value of learning result of both groups, experiment, and the control group can be seen in Table II below.

TABLE II. MEAN OF LEARNING RESUltof EXPERIMENTAL AND CONTROL GROUP STUDENTS

\begin{tabular}{|l|c|}
\hline \multicolumn{1}{|c|}{ Class } & Mean \\
\hline Experiment & 80,77 \\
\hline Control & 75,48 \\
\hline
\end{tabular}

Descriptive analysis can also be used to measure the thinking creative skill. After being taught using mindmanager-based learning media combined with wonder-share quiz creator, the thinking creatively skill showed that 5.01 and 3.90 averages for the experimental and control groups, respectively.

The mean (average) value of each indicator of thinking creatively skill of experimental group is detailed in Table 3 and in Table 4 for the control group.

According to Table III, it can be revealed that there are four indicators categorized in very high level, they are flexibility, fluency, originality, and elaboration. There is one indicator categorized in high level, it is bravery to take the risk. One indicator categorized in the moderate level, it is curiosity indicator. And the last is two indicators categorized into low level being complexity and imagination.

TABle III. Mean of EACH Indicator of CREATIVE Thinking AbILITy IN EXPERIMENTAL GROUP

\begin{tabular}{|l|l|c|c|c|c|c|}
\hline \multirow{2}{*}{ No } & \multirow{2}{*}{ Indicators } & \multicolumn{4}{|c|}{ Mean among students } & \multirow{2}{*}{$\begin{array}{c}\text { Common } \\
\text { mean }\end{array}$} \\
\cline { 3 - 6 } & & P.I & P.II & P.III & P.IV & \\
\hline 1. & Flexibility & 8,06 & 7,55 & 7,48 & 7,87 & 7,69 \\
\hline 2. & Fluency & 5,06 & 6,06 & 6,55 & 6,71 & 6,09 \\
\hline 3. & Originality & 4,32 & 5,39 & 5,32 & 6,19 & 5,30 \\
\hline 4. & Elaboration & 7,55 & 8,19 & 8,16 & 8,74 & 8,16 \\
\hline 5. & Complexity & 2,87 & 2,16 & 2,52 & 3,23 & 2,69 \\
\hline 6. & Bravery to take & 4,65 & 5,06 & 6,06 & 0,00 & 3,94 \\
& risk & & & & & \\
\hline 7. & Imagination & 2,81 & 2,48 & 2,77 & 0,00 & 2,01 \\
\hline 8. & Curiosity & 2,74 & 2,77 & 3,03 & 3,52 & 3,01 \\
\hline
\end{tabular}


TABEL IV.MEAN OF EACH INDICATOR OF CREATIVE THINKING ABILITY IN CONTROL GROUP

\begin{tabular}{|c|l|c|c|c|c|c|}
\hline \multirow{2}{*}{ No } & \multirow{2}{*}{ Indicators } & \multicolumn{4}{|c|}{ Mean among students } & $\begin{array}{c}\text { Common } \\
\text { mean }\end{array}$ \\
\cline { 3 - 7 } & & P.I & P.II & P.III & P.IV & \\
\hline 1. & Flexibility & 6,90 & 7,35 & 5,68 & 6,00 & 6,48 \\
\hline 2. & Fluency & 4,74 & 6,16 & 4,42 & 4,55 & 4,96 \\
\hline 3. & Originality & 4,71 & 5,00 & 3,48 & 4,13 & 4,33 \\
\hline 4. & Elaboration & 6,52 & 6,87 & 5,48 & 6,23 & 6,27 \\
\hline 5. & Complexity & 2,45 & 2,94 & 1,97 & 2,45 & 2,45 \\
\hline 6. & $\begin{array}{l}\text { Bravery to take } \\
\text { risk }\end{array}$ & 3,81 & 3,84 & 3,77 & 0,00 & 2,85 \\
\hline 7. & Imagination & 2,48 & 3,06 & 2,06 & 0,00 & 1,90 \\
\hline 8. & Curiosity & 2,81 & 2,52 & 2,35 & 2,48 & 2,54 \\
\hline
\end{tabular}

According to Table IV, it can be established that there are 3 indicators categorized into the very high level, they are flexibility, fluency, and elaboration. One indicator is categorized into a high level, i.e. originality. Two indicators are categorized into the moderate level, .e. bravery to take risk and curiosity. And two indicators are categorized into low level, .e. complexity and imagination.

\section{B. Inferential Statistics Analysis}

\section{1) Hypothesis Testing of Learning Result}

The hypothesis is tested by the independent-test. The testing criteria are as follows: there is significant difference if $p<\alpha(0,05)$, indicating that $\mathrm{H}_{0}$ is rejected or $\mathrm{H}_{1}$ is accepted. According to the independent t-test result, it obtained significance value $0.019<(\alpha)(0,05)$, indicating that $\mathrm{H}_{0}$ is rejected or $\mathrm{H}_{1}$ is accepted. this means that the hypothesis of this study is accepted in that there is the difference of learning result between students of which were taught using mindmanage- based learning media combined with wonder-share quiz creator and the students of which were control group in SMAN 5 Palu.

\section{2) Hypothesis Testing of Creative Thinking Ability}

This hypothesis was also run by independent-test and it was obtained a significance value $0.001<(\alpha)(0,05)$, resulting in $\mathrm{H}_{0}$ is rejected or $\mathrm{H}_{1}$ is accepted. As result, the hypothesis of this study is accepted in that there is the difference of Creative Thinking skills between students that have been taught using mind-manager based learning media combined with wondershare quiz creator and the students who were a control group. This means that there is a significant effect of the used minimanager-based learning media combined with wonder-share quiz creator to the thinking creatively skills of the 11th Grade Students in SMAN 5 Palu.

The result shows that learning result of the 11th-grade science students who have been taught by the used mindmanger-based learning media combined with wonder-share quiz creator is higher than that control group. This indicates that applying of the learning media can give a meaningful contribution to increasing students' learning result. This is consistent with the previous study done by [8] that the applying of mind-manager media can influence the learning result. The improvement is shown by the mean or average value of the learning result between the experimental group and the control group. The experimental group got 80.75 mean value, while the control group got 74.51. Mind-Manager is a medium that generated an idea in concept map in the form of text (words), pictures, and video. Percentage of concept map media is different with the usual powerpoint media. In mindmanager media, the percentage is displayed only with one layout. This is unlike that is displayed with the powerpoint which has several slides to show the presentation. Advantages of the mind-manager based media are also to have a high value of communication. As result, the students can have a great interest and an attraction to learn according to their own learning style as well as to affect the student learning outcomes. This is consistent with research conducted by [9] that the application of mind map conversion which states that learning through the implementation of the mindmap strategies can improve student learning outcomes, cognitive, affective, and psychomotor. Mindmap is also a visual representation idea through pictures and words. The strategies used combine icons, keywords, and color to maximize visualization of images or words displayed.

The application of mind-manager based media in learning is one of meaningful learning as proposed by Ref. [2] that meaningful learning is a process to associate new information with relevant concepts contained in a person's cognitive structure. This is consistent with the theory of [10], that the increasing of students mastery learning would also be influenced by an exercise to create a concept map given by the teacher, because the process of learning by using concept maps can cause the learning proses more meaningful, primarily this done by using new organizational structure.

Application of learning media using computer software like mind-manager based media proves that the media make the students easier to create concept maps, and the students are expected to be more easily understand the lessons. It can be seen from the learning result and creative thinking ability observation that is getting improved. This result proves that the research is consistent with the previous study by [11], which indicates that the application of mind maps allow students to be more easily understand the content, understand the relationship between content and memorize the overall concept. Additionally, using computer program is useful in creating mind maps that can be used with better efficiency like making a presentation. However, the teaching method is still considered as an important part that leads students to improve their knowledge. The reason that the learning outcomes of students taught using mind-manager based learning media combined with wonder-share quiz creator higher than the score of students' learning outcomes that are taught without the use of media-based learning. Once the process of material is completed, students are given exercises in quiz form through a wonder-share quiz creator software. Through the quiz exercises students become more eager to learn because when they finish answering the quiz, the score will be seen immediately. So the students can know the extent of their ability to understand the lessons. This is consistent with the theory forward by [12], that the wonder-share quiz creator has some easiness to use, which is based on the feedback and responds feature, and the feature that displays the test results 
and steps that will be followed by the test taker based on responses/answers entered.

Another study supports the results of this study has been reported by [13], that application of mind-manager effect on learning outcomes biology in the 11th-grade science students of SMAN 2 Takalar on plant tissue concept. Mind-manager based media allows teachers to organize information in a structured way. Therefore, the application of learning media needs to be applied in the learning process in the classroom. This is consistent with the theory put forward by [14] that in the learning activities required learning media presence. Teachers realize that the complicated learning materials will be more difficult to understand by students without learning media. In addition, a similar study has been conducted [15] effect of IT-Based Concept Map Implementation on Students' Cognitive Outcome about cells lesson at 11th Grade Science Class in SMAN 1 Pamboang". The study found that there is a positive effect of the application of IT-based concept map to students' cognitive achievement, indicated by the higher learning result or the increase of score test in experimental class than the control class.

In addition to a positive effect of learning result, mindmanager based learning media combined with wonder-share quiz creator also showed that this learning media can think more creatively. These results are shown in the descriptive and inferential statistical analysis. From the eight indicators of the creative thinking ability, we can see some indicators that are categorized into"very high" level, such as flexibility, fluency, originality, and elaboration.Whereas, the control class, indicators that have very high category are only flexibility, fluency, and elaboration.

The aspect observed in the fluency indicators is an ability to answer or to solve the problem. If students can answer more than one question, it means that this indicator has been reached. This is shown in experimental class $\left(11^{\text {th }}\right.$ Grade of Science), after being taught by concept map based learning media, each student in their own group can give an answer according to their own idea. It is different from the students who are the control group, the students memorize the answer or the solution of the problems/questions. The same case happens to creative thinking skill. In this aspect, the students have been able to give various divergent answers. This is consistent with the theory forwarded by [16], that thinking creatively is thinking activity to create something creative and original. later, Ref. [16] conveyed that thinking creatively is the synonym of thinking divergently. One of the indicators of thinking divergently is fluency. That means an ability to generate many ideas.

Elaboration indicator is one of thinking creatively.This is one of aspect observed, actively and fully of spirit for finishing in group tasks. Conversely, students in control class have less interest and ability. That statement is consistent with theory conveyed by Ref.[17] that to develop creative thinking skill, students have to be active students. If students are to be active, teachers should give the widest opportunity to students to tell their ideas and experiences in the learning process.

Indicator categorized into "moderate" level is curiosity. The aspect observed is an ability to ask about the lesson that is discussed. Students in each group ask about some lesson that is still poorly understood. From the explanation above, it has been clearly defined that creative thinking skill of students using mind-manager based learning media combined with wonder-share quiz creator is higher than the students taught without any media. This is consistent with research conducted by [18], that the average of students' skill of thinking creatively is higher when they are taught with mind mapping method than the students who are still following the conventional method of learning.

\section{IV.CONCLUSION}

1) Mind-manager based learning media combined with wonder-share quiz creator has an effect on students' learning result in SMAN 5 Palu

2) Mind-manager based learning media combined with wonder-share quiz creator combined with wonder-share quiz creator has an effect on students' skill of thinking creatively in SMAN 5 Palu

Based on the conclusion mentioned above, it is suggested as follow:

1) Mind-manager based learning media combined with wonder-share quiz creator can be one alternative learning media to increase learning result and boost skill of thinking creatively.

2) Mind-manager based learning media combined with wonder-share quiz creator should be adjusted to the current lesson and the media should be designed more interesting in order to the students can be more motivated and challenged to study, and it is expected to increase students' learning result and skill in thinking creatively.

\section{REFERENCES}

[1]. Kasim. A, Pengaruh Strategi Pembelajaran Kooperatif Think Pair Share Terhadap Kemampuan pemecahan Masalah Ekologi dengan Gaya Kognitif Berbeda. Disertasi Program Doktor Universitas Negeri Malang tidak dipublikasikan, 2014

[2]. Abimanyu. S, Lipu. S, Strategi Pembelajaran. Jakarta: Direktorat Jenderal Pendidikan Tinggi Depatemen Penddikan Nasional, 2008

[3]. Hamalik. O, Kurikulum dan Pembelajaran. Jakarta: Bumi Aksara, 2008

[4]. Yoga. D, Petunjuk Praktis Untuk Menerapkan Kegiatan Belajar Mengajar Berbasis Mind Map. Diakses tanggal 18 Mei 2015

[5]. Sari, P. M, Penggunaan Media Pembelajaran Interaktif Berbasis Wonder Share Quiz Creator untuk Meningkatkan Motivasi dan Kemandirian Belajar Siswa. Skripsi. Jember: Program Studi Pendidikan Ekonomi FKIP, 2012

[6]. Sugiyono, Metode Penelitian Pendidikan. Bandung: Alfabeta. 2011

[7]. Setyosari. P, Metode Penelitian Pendidikan dan Pengembangan. Jakarta: Kencana. 2010

[8]. Adelia. R, Pengaruh Penerapan Media Pembelajaran Mind-Manager Pro 7 terhadap Hasil Belajar Biologi Siswa pada Konsep Sistem Reproduksi. Skripsi. Jurusan Biologi FMIPA UNM. 2012

[9]. Aditya, N, H. Susilo. Penerapan Mind Map Conversion Back to Back Berbasis Lesson Study untuk Meningkatkan Pemahaman Konsep, Retensi Mahasiswa Jurusan Biologi Pada Mata Kuliah Fisiologi Tumbuhan Universitas Malang. Prosiding Seminar Nasional Pendidikan Biologi, 2015.

[10]. Holil. A, Peta Konsep untuk Mempermudah Konsep Sulit dalam Pembelajaran. Diakses tanggal 22 Februari 2016

[11]. Tungprapa. T, Effect of Using the Electronic Mind Map in the Educational Research Methodology Course for Master-Degree Students 
in the Faculty of Education. International Journal of Information and education Technology. No. 11 Vo. 5, pp 803-807. 2015

[12]. Hernawati. K, Modul Membuat Quiz/Evaluasi dengan Wondershare Quiz Creator. Yogyakarta: Jurusan Pendidikan Matematika FMIPA UNY. 2015

[13]. Suprawan, Pengaruh Penerapan Mind-Manager terhadap Hasil Belajar Siswa Kelas XI IPA SMA Negeri 2 Takalar pada Konsep Jaringan Tumbuhan. Skripsi. Makassar: Program Studi Pendidikan Biologi FMIPA UNM. 2012

[14]. Djamarah, S. B, A. Zain, Strategi Belajar Mengajar. Jakarta: RinekaCipta. 2010
[15]. Musyrifah, Ismail, Pengaruh Penerapan Peta Konsep Berbasis IT terhadap Hasil Belajar Kognitif Biologi Siswa Kelas XI IPA SMA Negeri 1 Pamboang pada Materi Sel. Jurnal Bionature. No.1 Vol 15, pp 6-15. 2013

[16]. Bagus, P. I, Pengembangan Peta Pikiran untuk Peningkatan Kecakapan Berpikir Kreatif Siswa. Jurnal Pendidikan dan Pengajaran UNDIKSHA. No. 5 Vol.3, pp 670-683. 2007

[17]. Munandar, Pengembangan Kreativitas Anak Berbakat. Jakarta: Rineka Cipta, 2004

[18]. Okta Priantini, D.A.M, Pengaruh Metode Mind Mapping terhadap Keterampilan Berpikir Kreatifdan Prestasi Belajar IPS. E-Jurnal.Vol.3, 2013 